\title{
Bank-Line Behaviour of the Main Rivers Located Within Sundarbans Using Digital Shoreline Analysis System
}

\author{
Md. Manjurul Anam1, Abdullah-Al-Jabir ${ }^{2}$, and G. M. Jahid Hasan ${ }^{3 *}$, \\ Department of Civil Engineering, Military Institute of Science and Technology (MIST), Dhaka, Bangladesh \\ emails: 1anam368027@gmail.com; 2jishraq@gmail.com; and *3jahid@ce.mist.ac.bd
}

\section{ARTICLE INFO}

Article History:

Received: 20th February 2021

Revised: 05th April 2021

Accepted: 07th April 2021

Published: 27th June 2021

\section{Keywords}

Landsat images

Manual digitization

DSAS

ArcGIS

Bank-line movement

Rivers of Sundarbans

\begin{abstract}
A B S T RACT
Sundarbans, the largest mangrove forest located over the GBM basin, has impacted lives of millions over the years. Standing against various natural disasters, rivers of Sundarbans have undergone major issues such as erosionaccretion of both the banks. The paper deals with a combination of remote sensing and Digital Shoreline Analysis System (DSAS), studying temporal behaviour of bank-lines along the main rivers of Sundarbans for the last three decades. The course of main rivers spanning from southwest Baleswar to west Bengal Bidyadhari within coverage of $10,000 \mathrm{sq}$. $\mathrm{km}$. has been analyzed in this study. DSAS, the extension tool of ArcGIS, was used for monitoring the rate-ofchange from multiple historic bank-line positions extracted from satellite images. Comparison of historic bank-lines between different rivers of Sundarbans was done based on Net Bank-line Movement (NBM) with an interval of five years. Finally, the results were presented graphically to get a better understanding of the bank-line behaviour. The study revealed that the western region of mangrove prevails eroding behaviour than the eastern region. Increased rates of riverward movement due to accretion was found from 20082013. These results are important for future monitoring and proper management within the coastal communities surrounding the mangrove forest.
\end{abstract}

(C) 2021 MIJST. All rights reserved.

\section{INTRODUCTION}

Bengal delta, extending offshore ward in the Bay of Bengal as a clinoform (sloping depositional surface) was formed during the last 11,000 years within the Bengal basin (Mikhailov and Dotsenko, 2007; Kuehl et al., 2005). With years of climate change, degrading of coastal areas will endanger lives to millions and coastal infrastructures. Such a situation can be more appalling for low-lying deltaic regions like Bangladesh which are less organized to cope-up with the risks related to climate change issues (Kanwal et al., 2019). The south-west coastal zone of Bangladesh which represents the largest mangrove forest, Sundarbans, which is ecologically fragile and climatically vulnerable, serves home to 4.5 million people. Such mangrove forest contributes to a variety of ecosystem services proved to be advantageous for the protection of shorelines from erosion caused by storms and waves and accelerating sediment accretions (Sathirathai and Barbier, 2001). Their exceptional root system with physical roughness helps in capturing and storing valuable quantities of sediment both from highland as well as oceanic origin (Rahman et al., 2011). Above all, mangrove morphology and sedimentation indicate the interaction between sea-level changes, sediment entrapment, and coastal processes (Souza Filho et al., 2006; McIvor et al., 2013; Gilman et al., 2007 etc).

Landforms within active coastal areas are dynamic in nature (Sheik and Chandrasekar, 2011). They are uninterruptedly modified by natural and man-made processes causing streams of Sundarbans to be threatened. Areas of Sundarbans are categorized by stream channels and creeks of changing widths, from a few meters to several kilometers (Sahana and Sajjad, 2019). Almost 85\% of people living in Sundarbans are dependent on agriculture. Erosion-accretion can augment challenges to coastal habitats (e.g., Katz and Mushkin, 2013; Collins and Sitar, 2008; Moore and Griggs, 2002; Benumof et al., 2000 ; etc.) as well as river systems. Therefore, it is important to understand the extent of land- and river-ward retreat of riverbanks at different timescales (Katz and Mushkin, 2013; Esteves et al., 2011).

Application of Digital Shoreline Analysis System (DSAS) is one of the feasible tools which can be used in the analysis of changes over historical timescales. The DSAS 
is an extension to ArcMap and is famous to generate measurements of transects either automatically or manually. These transects based on user-specified parameters develop metadata for calculating rates of changes and providing other useful statistical information (Thieler et al., 2009). Generally, DSAS is widely used in studying shoreline dynamics of coastal areas i.e., coasts of India, Italy, Turkey, USA, Vietnam etc (Hegde and Akshaya, 2015; Moussaid et al., 2015 etc). Since DSAS is effective for calculating changing rates incorporating an evidently identified attribute position at different times (Sheik and Chandrasekar, 2011; Cohen and Lara, 2003), it is capable to present the overall scenario with a better understanding of the trends and dynamics of river banklines as well. However, utilizing DSAS methodology, which is generally used for delineating shorelines, an initiative was taken in this study to investigate the changing trend of river bank-lines along the main rivers of the Sundarbans. According to the author's knowledge, so far, no study has been conducted to monitor the dynamics of river bank-lines using DSAS tool. It is anticipated that this advanced technique of GIS-based tool would represent an overall scenario of the landform conditions along the mangrove delta for an effective coastal zone management strategy against effects of sea-level rise and other effects due to changing climates.

\section{STUDY AREA}

The study area emphasizes the changing trends of bank-lines of eight main rivers located within Sundarbans namely Baleswar, Pussur, Shibsa, Arpangasia, Bara Pangga, Harinbhanga, Raimangal, Bidyadhari (rivers are displayed in Figure 1). Among the rivers, the Bidyadhari River is located within the Indian part of Sundarbans whereas the remaining seven rivers exist in the Bangladesh part. Starting from the western part of Sundarbans, the Harinbhanga River falls along the India-Bangladesh border. Adjacent to this River, the Raimangal River is situated occupying the South 24 Parganas district of India along with the Satkhira District of Bangladesh. About $220 \mathrm{~km}$ southwest of Dhaka, the Arpangasia River is in the province of Khulna originated after the Kholpetua River. Bara Pangga River, the smallest River within the study area, lies at the end of the Arpangasia River. The other main important rivers are the Shibsa and Pussur River. The Shibsa River is about $100 \mathrm{~km}$ long and located within Khulna region. Inside the Sundarbans mangrove forest, the Shibsa River meets the Pussur River, and then split up again near Mongla, before merging the Bay of Bengal. Approaching towards the Bay of Bengal, at the downstream region lays the Hiron point tide station. Being distributaries of the Ganges, the Pussur River lies at the eastern part of Sundarbans right next to Baleswar River. The Baleswar River forms within part of the Bagerhat and Barguna District. Among all the above discussed rivers in the Bangladesh part, Baleswar, Pussur, Shibsa and Arpangasia are approximately $100 \mathrm{~km}$ long. Figure 1 depicts all the rivers located within the mangrove forest.

\section{MATERIALS AND METHODS}

\section{A. Collection of Satellite Images}

NASA initiated the Landsat program for the first time in early 1970 due to a lack of appreciation of terrain data. Within a decade, Landsat 1-3 were launched though they were not applicable for precise studies mainly because of poor resolution. Landsat 4 was launched in 1982 which was collecting data until 1993. Landsat 5 was launched in 1984 which delivered earth imaging data for nearly twentynine years and finally decommissioned in 2013. Landsat 7 was launched in 1999 and in late 2020 Landsat 7 was replaced by Landsat 9 .

The basic data used in this study were based on Landsat images freely available for research purposes. The images provide information within the resolution of $30 \mathrm{~m} \times 30 \mathrm{~m}$, any object less than this scale remains undetectable. Images of the short-wave infrared band were selected for this study. Hence, band 5 of Landsat 4-5 (1.55-1.75 $\mu \mathrm{m})$ (for the years 1989, 1993, 1998); Landsat $7(1.55-1.75 \mu \mathrm{m})$ (for the years 2003, 2008); and Landsat $8(0.85-0.88 \mu \mathrm{m})$ (for the years 2013, 2018) were used for separating land and water interfaces. Thematic Mapper (TM) of Landsat 4-5 and Enhanced Thematic Mapper Plus (ETM+) of Landsat 7 are widely used datasets for land surface and water mapping (Masocha et al., 2018). Besides, Landsat 8 is equipped with Operational Land Imager (OLI) sensor which has the potential to extract land surface and water information (Wenbo et al., 2013). Many previous studies have observed the performance of water indices using Landsat 8 OLI sensor (Wenbo et al., 2013; Ji et al., 2015). All the Landsat images required for this study were collected from the United States Geological Survey web domain (http:// earthexplorer.usgs.gov).

\section{B. Categorization of Images}

Images with lesser cloud cover and clear visibility were selected during the initial screening process. Dry season images were preferred from November to March. For each year, two scenes (path/row - 137/45 and 138/45) of Landsat images were used to capture the entire Sundarbans as can be seen from Figure 1. Changes of river bank-lines in every year interval are not that effective as the changes are minor and not detectable for $30 \mathrm{~m}$ resolution image, for which images were taken at an interval of 5 years. Another interval i.e., 4 years also considered due to the unavailability of good quality images for a particular year.

\section{Sorting of Images}

As large tidal ranges are observed in the Bay of Bengal (Murty and Henry, 1983), it is required to ensure that the satellite images collected for a particular year represent almost identical tidal water level conditions for other year images. Unless all the collected images correspond to similar tidal conditions (i.e., all images acquired during either high tide or low tide), river bank-line change detection will be largely inaccurate since the rivers are located near the estuary mouth with a flat slope. With a view of avoiding such error, the tidal water levels of all the collected images were checked by noting the image acquisition date and time, and tidal water level records collected by the Bangladesh Inland Water Transport Authority (BIWTA) at that time. High tide condition was considered as the reference and collected images showing good agreement in terms of tidal water level condition. 


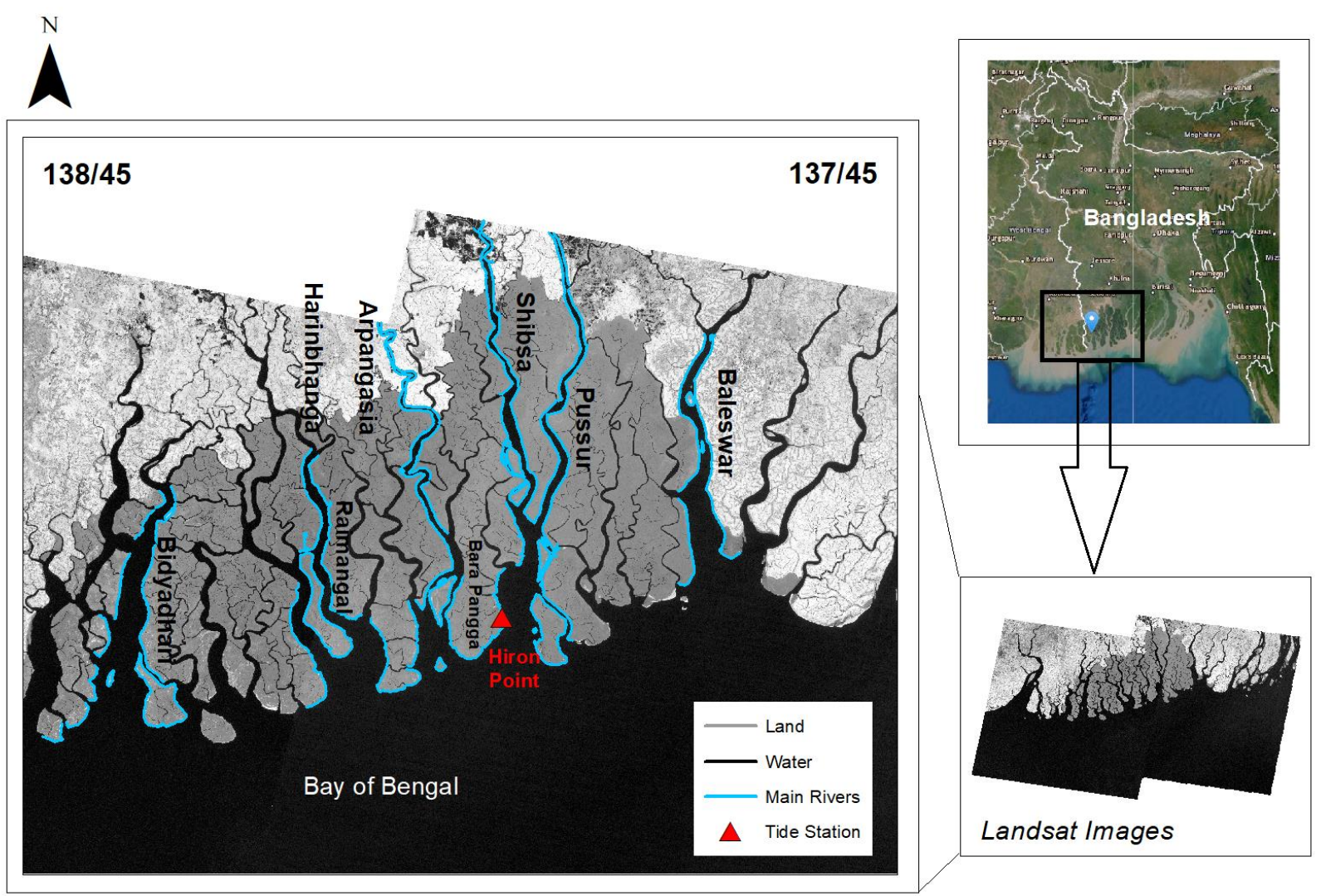

Figure 1: Main Rivers located within the Sundarbans where blue colour indicates riverbanks; black and grey colour indicates water and land area. Solid triangle indicates tide station

Table 1

Tidal water levels during the image acquisition date and times

\begin{tabular}{|c|c|c|c|c|c|c|c|}
\hline Timeline & Path-Row & Landsat No & $\begin{array}{c}\text { Acquisition } \\
\text { Date }\end{array}$ & $\begin{array}{l}\text { Acquisition } \\
\text { Time GMT }\end{array}$ & $\begin{array}{c}\text { Tide } \\
\text { Level }(\mathbf{m})\end{array}$ & $\begin{array}{c}\text { Tidal } \\
\text { Condition }\end{array}$ & $\begin{array}{c}\text { Reference } \\
\text { Station }\end{array}$ \\
\hline \multirow{2}{*}{1989} & $137-45$ & 5 & $2 / 21 / 1989$ & $3: 54 \mathrm{AM}$ & 2.1 & \multirow{14}{*}{ High Tide } & \multirow{14}{*}{ Hiron Pont } \\
\hline & $138-45$ & 4 & $1 / 19 / 1989$ & 4:03 AM & 1.8 & & \\
\hline \multirow{2}{*}{1993} & $137-45$ & 5 & 11/12/1992 & 3:46 AM & 2.5 & & \\
\hline & $138-45$ & 5 & 1/22/1993 & 3:52 AM & 1.9 & & \\
\hline \multirow{2}{*}{1998} & $137-45$ & 5 & 2/14/1998 & 4:01 AM & 1.5 & & \\
\hline & $138-45$ & 5 & 3/9/1998 & 4:07 AM & 1.9 & & \\
\hline \multirow{2}{*}{2003} & $137-45$ & 7 & $1 / 19 / 2003$ & 4:13 AM & 2.3 & & \\
\hline & $138-45$ & 7 & $11 / 23 / 2002$ & 4:19 AM & 2.0 & & \\
\hline \multirow{2}{*}{2008} & $137-45$ & 5 & $11 / 24 / 2008$ & 4:08 AM & 2.2 & & \\
\hline & $138-45$ & 7 & $12 / 25 / 2008$ & 4:20 AM & 2.3 & & \\
\hline \multirow{2}{*}{2013} & $137-45$ & 7 & $2 / 15 / 2013$ & 4:21 AM & 1.5 & & \\
\hline & $138-45$ & 7 & $2 / 22 / 2013$ & 4:27 AM & 1.8 & & \\
\hline \multirow{2}{*}{2018} & $137-45$ & 8 & $1 / 20 / 2018$ & 4:24 AM & 1.6 & & \\
\hline & $138-45$ & 8 & $2 / 28 / 2018$ & 4:30 AM & 2.5 & & \\
\hline
\end{tabular}

Images with low tide condition were discarded and replaced with new suitable satellite images of different periods. To accomplish this, a wide-ranging search of the USGS Earth Explorer interface was conducted for November to March whenever deemed necessary. This was done due to cloud-free and tide-synchronous images during dry months are not always available. Table 1 shows the tidal water level checks performed covering the study periods along with the Landsat numbers. Tide gauge station located at Hiron Point (operated by the BIWTA) was used to perform the water level checks. The location of the station is shown in Figure 1. Tidal water level check is done for both the scenes of Landsat (Path-Row: 137-45 and 138-45). Thus, from 1989 to 2018, a total of 14 images were finally selected for analysis. 


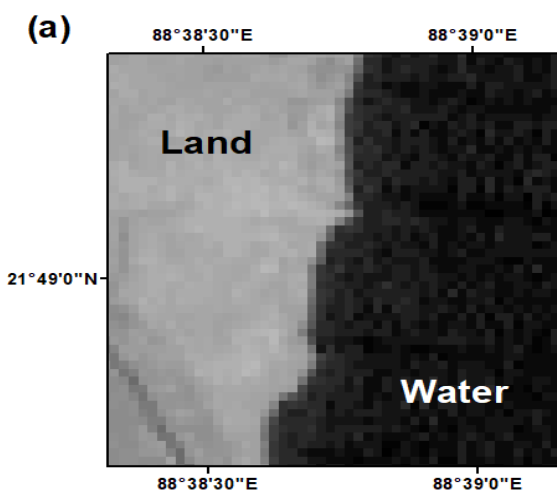

(b)

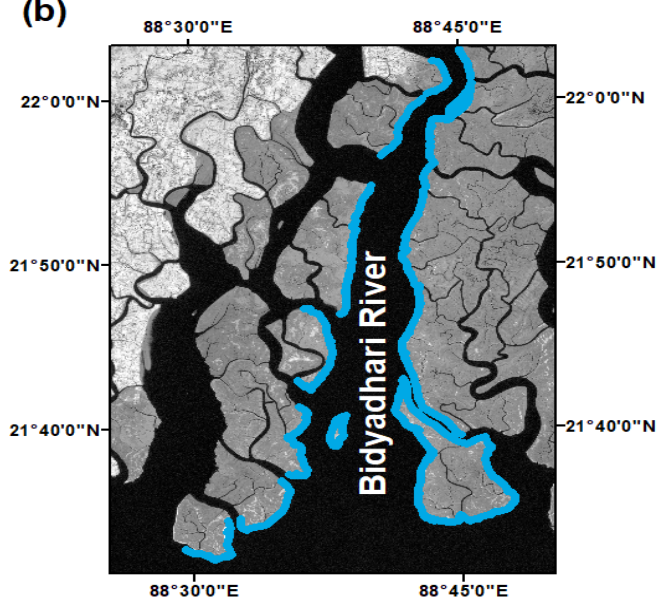

(c)

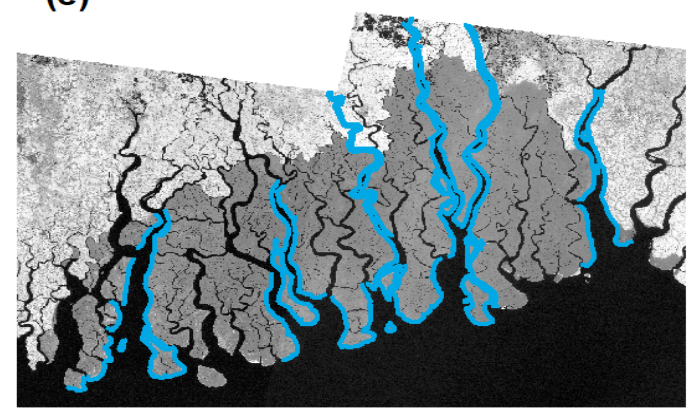

$8^{\circ} 38^{\prime} 30^{\prime \prime} E$

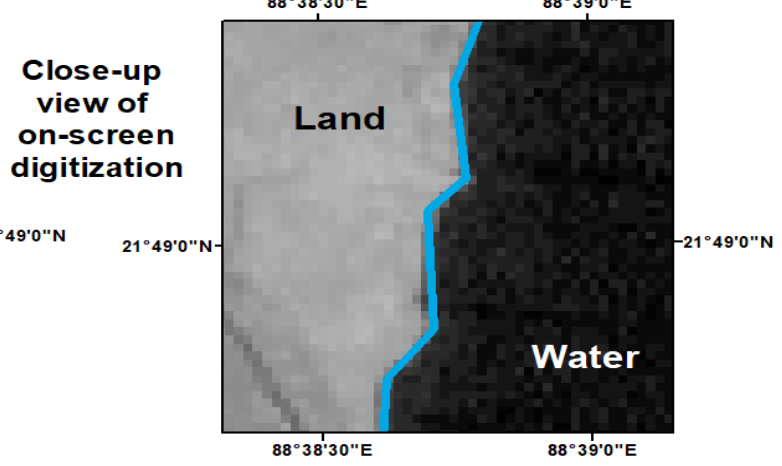

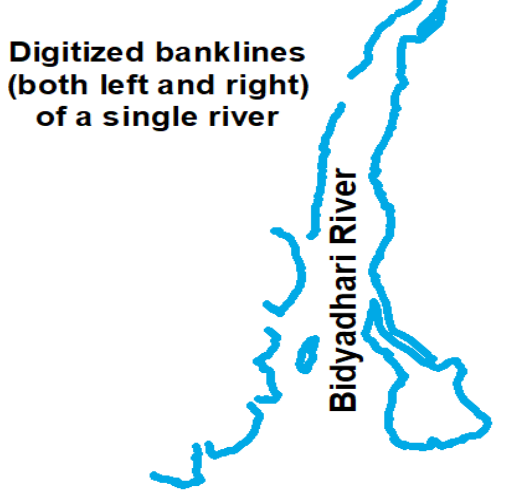

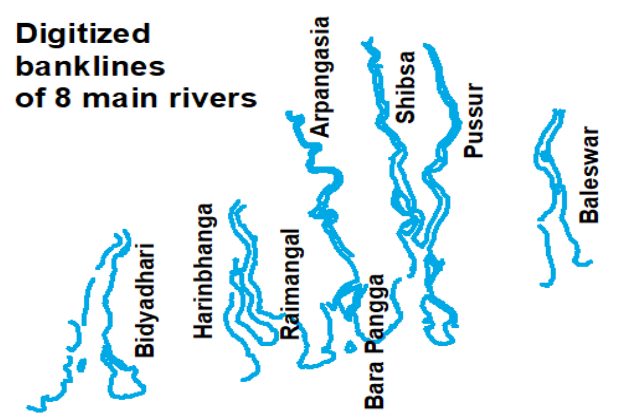

Figure 2: Manual digitization of riverbanks: (a) separation of land and water body by manual on-screen digitization, (b) digitized bank-lines of a sample river extracting from raw satellite image, and (c) digitized bank-lines of all the study rivers within Sundarbans

\section{Digitization of River bank-Lines}

Bank-lines can be delineated using several methods i.e., manual digitization, band rationing, density slicing, fuzzybased classification, etc. Besides, there are several ways to digitize i.e., digitizing on-screen over an image, digitizing a hard copy of a map on a digitizing board, or using automated digitization by converting an image into different indexes. However manual digitization is one of the most common methods used for land-water boundary identification. Many previous studies performed using this method (Matin and Hasan, 2021; Nabi et al., 2016; Sarkar et al., 2012 etc). Practically, the manual digitization method seemed to be time-consuming and boring and may not highly effective when a huge number of images need to be analysed, but still proven to be the most accurate method. Since for this study the number of images is not huge, the manual digitization method was considered for bank-line delineation.

Images of selected bands (i.e., short wave infrared band) exhibit strong reflectance by soil and vegetation, and absorbance by water (i.e., Frazier and Page 2000; Kuleli 2010 etc) are used in this study. The river bank-lines of the main rivers of Sundarbans were digitized using on-screen manual method and explained pictorially in Figure 2. Marking the land-water boundary with proper utilization of polyline features of ArcGIS, complete digitization of the riverbanks (both left and right) was performed for all the year images. A total of 16 bank-lines were manually digitized for a single year Landsat scene. Shapefiles of riverbanks were generated with a projected coordinate system of WGS_1984_UTM_Zone_46N. A similar approach of image collection, sorting and digitization was used by Matin and Hasan (2021) for their study covering the entire coastline of Bangladesh. 

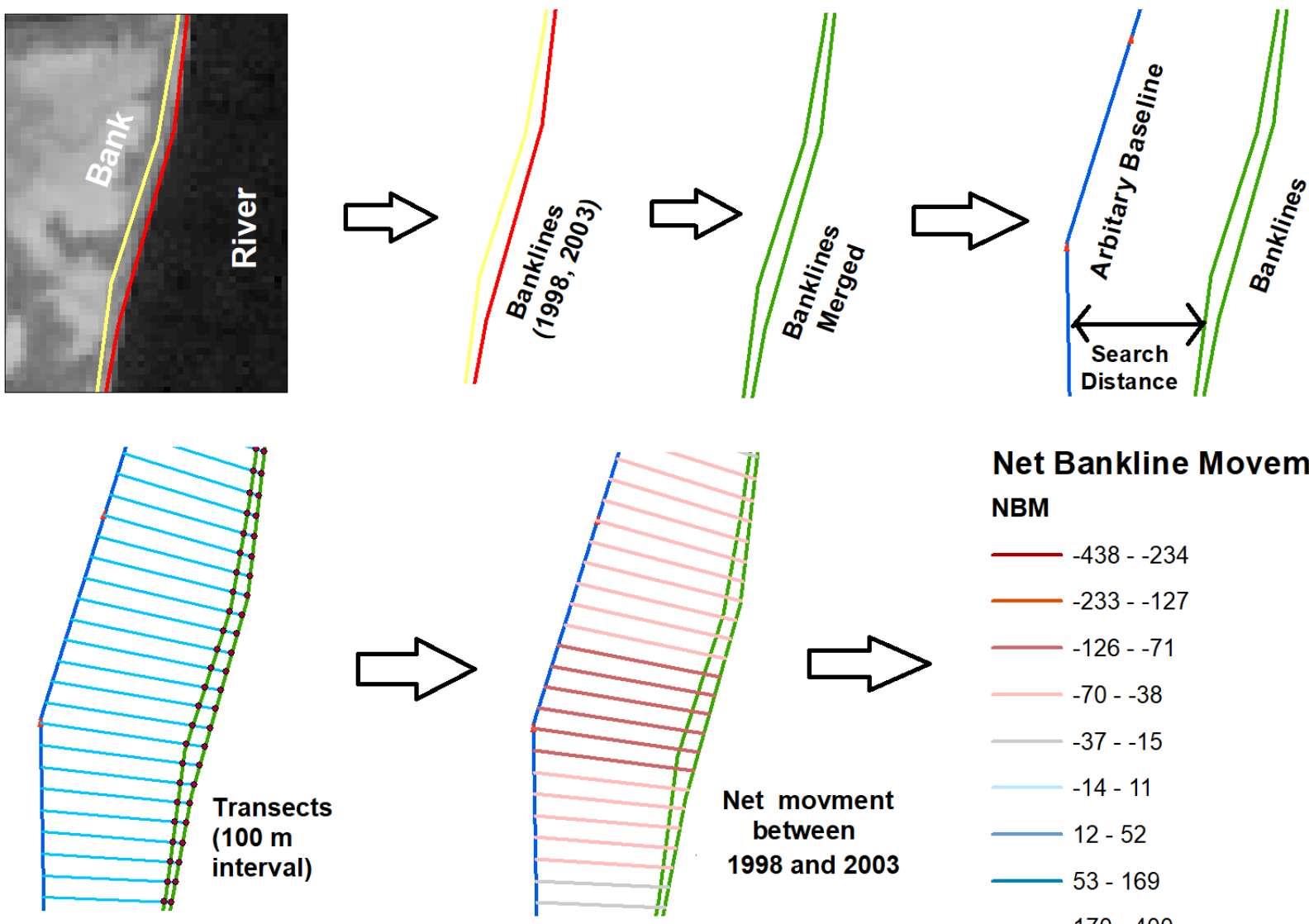

Net Bankline Movement NBM

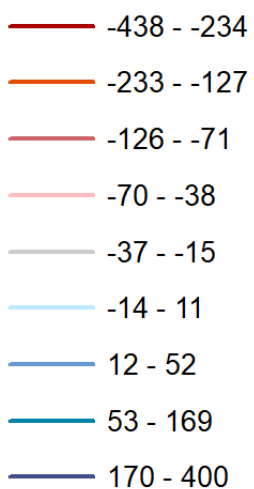

Figure 3: Digital Shoreline Analysis System (DSAS) utilized to determine the net movement between the bank-lines of 1998 and 2003

\section{E. Bank-Lines Interpretation Using DSAS}

DSAS enables a user to calculate statistics of rate-ofchange from multiple historical bank-line positions. Generally, two versions of DSAS are available: the DSAS extension of the Environmental System Research Institute (ESRI)'s ArcGIS software and the web version of DSAS (Thieler et al., 2009). The web-based version was adopted in this study because of its faster performance. Records from previous shoreline studies carried out along the coastline showed successful application of DSAS i.e., Ellison and Zouh (2012) - Douala estuary, Cameroon; Appeaning Addo et al. (2008) - Accra, Ghana; Natesan et al. (2013) - Vedaranyam coast, Tamil Nadu; Kuleli (2010) - Mediterranean coast, Turkey; Hapke et al. (2009) California coast, USA; To and Thao (2008) - Nam Dinh coast, Vietnam; Nguyen et al. (2015) - Kien Giang coast etc. However, none of them were observed to apply DSAS for analysing river bank-lines.

For using DSAS, firstly a baseline has to be considered along a river channel in such a way that the baseline should be almost perpendicular to the bank-line. The baseline acts as a reference line parallel to a bank-line, with respect to which the DSAS calculates the movement of different bank-lines. The DSAS requires the position of land and water body to be ascertained along the baseline for determining the movement of the bank-lines. The application of DSAS casts transects which intersect each bank-line to create a measurement point, and these measurement points calculate the changing rates of river bank-lines.

The DSAS was applied to the extracted bank-lines of the rivers of Sundarbans and explained in Figure 3. Transects shown in the figure represent the bank-line movement between two years via color ramps which are categorized into different ranges. All transects change into different colors according to the range or linear distance that the position of the bank-line changes on that location. Each transect represents the value of total bank-line movement of the location in which the transect is present. The positive values indicate accretion that is, riverward movement of the bank-lines. On the other hand, the negative values indicate erosion which is the landward movement of the bank-lines. The maximum distance between the baseline and the bankline was set as $650 \mathrm{~m}$ (using trial and error, depending on the distance between the baseline and bank-line) and the distance between each transect was set to be $100 \mathrm{~m}$. Finally, net bank-line movement (NBM) was calculated running the statistical option of the DSAS tool named Net Shoreline Movement (NSM). Net bank-line movement estimates the distance between the first and the last bank-lines. The rate of bank-line movement for both left and right banks was then analyzed graphically and as a sample movement of two rivers is displayed in Figure 4 and 5. 

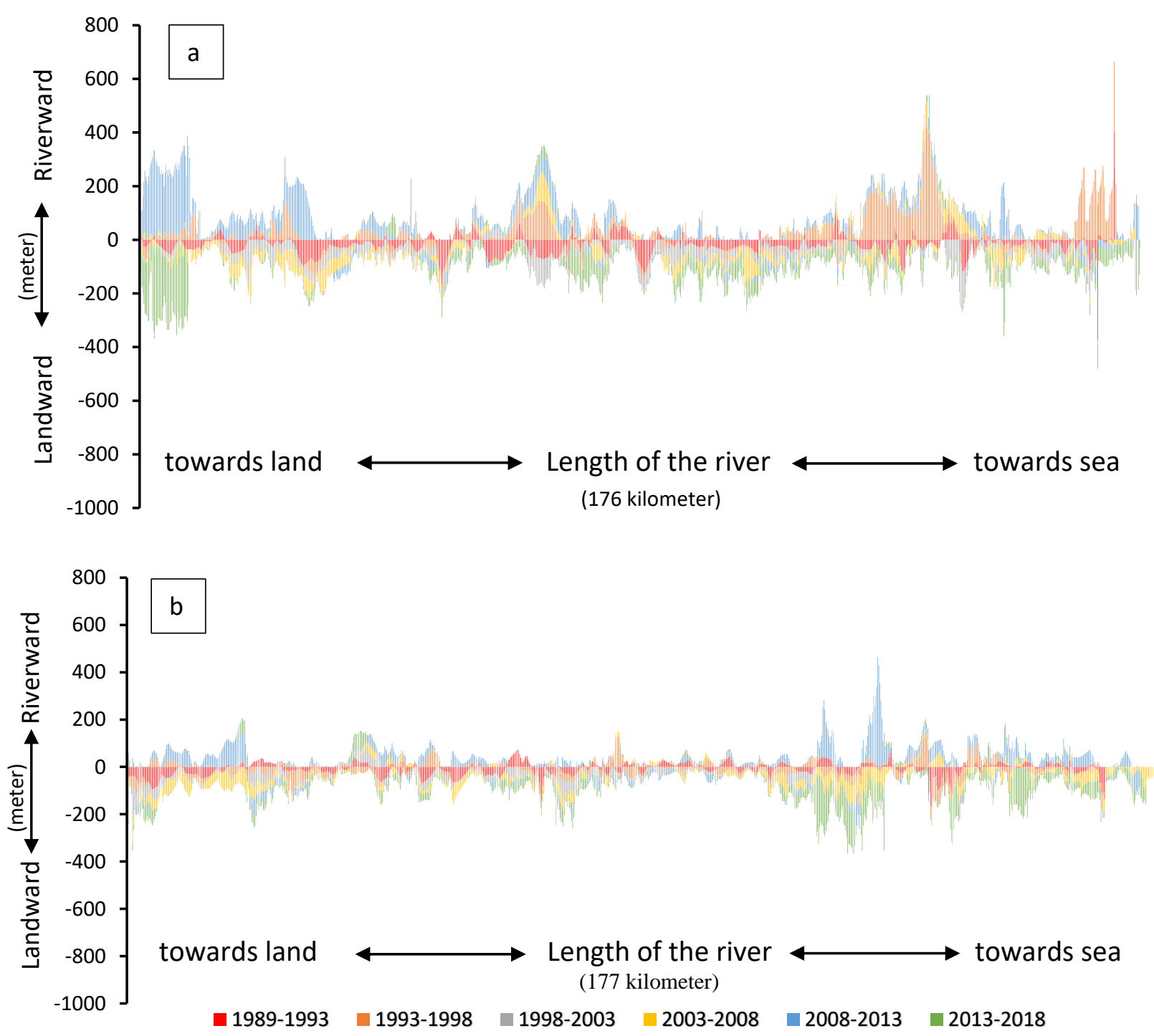

Figure 4: Graphical representation of net bank-line movement (a) left bank and (b) right bank of Pussur River from 1989 to 2018 utilizing NBM (Net Bank-line Movement) of DSAS toolbar in which negative values indicate erosion or landward movement and positive values for accretion or riverward movement

\section{RESULTS AND DISCUSSION}

The estimated net bank-line movement of the Pussur River is shown in Figure 4. From the figure, it can be observed that most of the regions of the left bank maintained a movement within $100 \mathrm{~m}$ (Figure 4a) during 1989-2018. During 1993-1998, a maximum riverward movement of more than $400 \mathrm{~m}$ is observed at a few locations. From 2008-2013, a portion in the upstream is faced riverward movement of more than $300 \mathrm{~m}$ which became totally opposite during 2013-2018. The highest amount of change that occurred to the right bank is around $500 \mathrm{~m}$ during 2008-2013 (Figure 4b). For the rest of the study periods, the movement remained almost identical except few locations during the 1990s.

Whereas the Arpangasia River (Figure 5) maintained a landward movement not greater than $50 \mathrm{~m}$ for almost all the locations during 1989-1993. From 1993-1998, the bank-line showed similar characteristics in most of the locations. Riverward movement is dominating than landward during 1989-1993. The density of bank-line movement is more with less intensity from 1989-2003 compared to the movements from 2003-2018 during which change is observed to occur in few locations but with large magnitude (Figure 5). Continuous and random movement of the bank-lines is observed for the right bank of Arpangasia River during the whole study period. During each interval, gentle movement of either landward or riverward is found. Figure $5 \mathrm{~b}$ shows that the locations have undergone riverward movement during 1989-1993 which changes towards landward during the next 5 years which again became opposite for the next interval. 

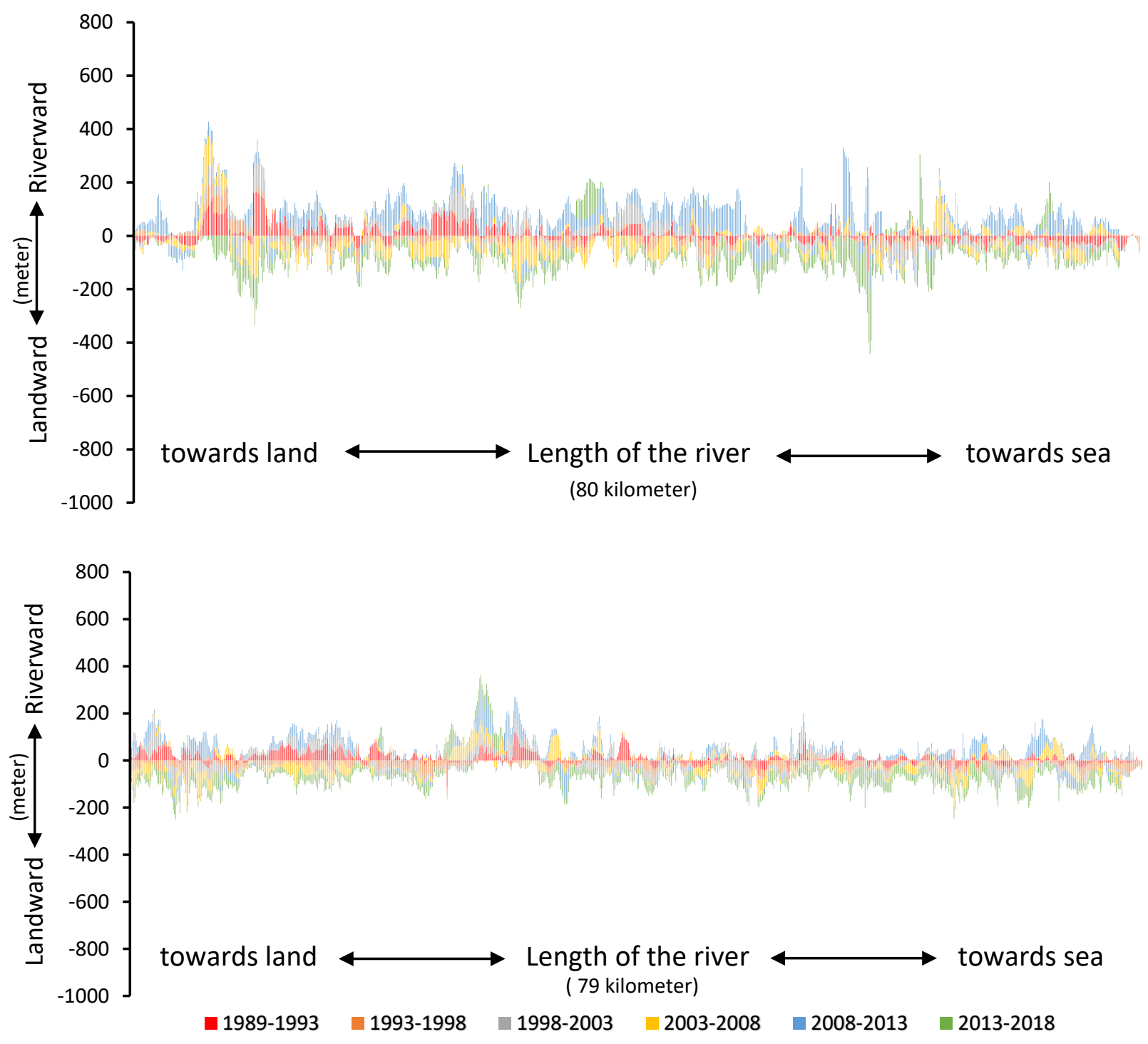

Figure 5: Graphical representation of net bank-line movement of left bank (upper panel) and right bank (lower panel) of Arpangasia River from 1989 to 2018 utilizing NSM (Net Shoreline Movement) of DSAS toolbar in which negative values indicate landward movement or erosion and positive values for riverward movement or accretion

Net bank-line movements are scrutinized more in the right bank than left banks of the Baleswar River from 1989 to 2018. Bank-lines shifting towards land are considered as land loss or erosion and towards river or water is considered as land gain or accretion. The highest riverward movement on the right bank is observed over $500 \mathrm{~m}$ whereas on the left bank observed $400 \mathrm{~m}$. The highest landward movement marked about $600 \mathrm{~m}$ in left bank whereas in right bank observed about $400 \mathrm{~m}$. Figure 6 illustrates the net bank-line movement of the Baleswar River from 1989 to 2018.

The banks of the Shibsa River had undergone random movement in almost all the locations along the channel length. Both the banks show non-sequential and nonuniform movements with similar characteristics during the study period (Figure 6). Though the riverbanks went through large changes for the whole period, they had undergone most alterations between 2008 and 2013.
The left bank of the Bidyadhari River has undergone continuous landward and riverward movement along the channel. Along most of the locations, the movement is observed to be less than $200 \mathrm{~m}$ which stands both for landward and riverward. But the bank-line severely changed near the coast where the Bay of Bengal lies. Particularly from 1993-1998 (Figure 6), the bank-line near the coast faced a large amount of riverward movement where a change of more than $400 \mathrm{~m}$ is observed. During the period 2013-2018, a riverward movement of more than $800 \mathrm{~m}$ occurred near the coast. But the observation has shown very little change along the entire channel during 2008-2013. The picture shows that the right bank of the river changed its position both landward and riverward for around $500 \mathrm{~m}$ in some regions during 1993-1998. Unlike the left bank of the river, the entire right bank went through random movement of its bank-line. 

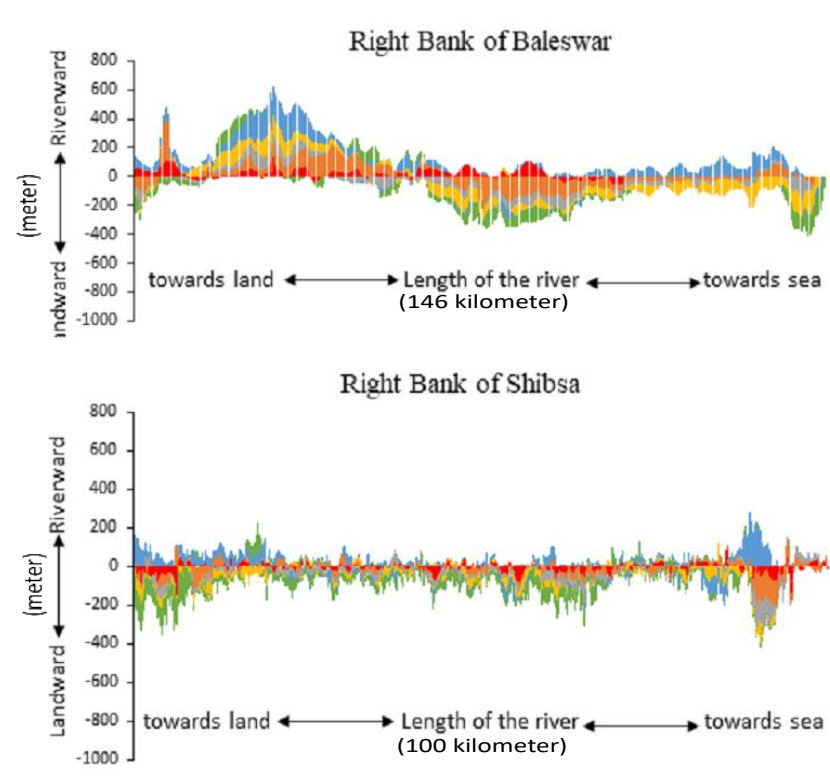

Right Bank of Bidyadhari

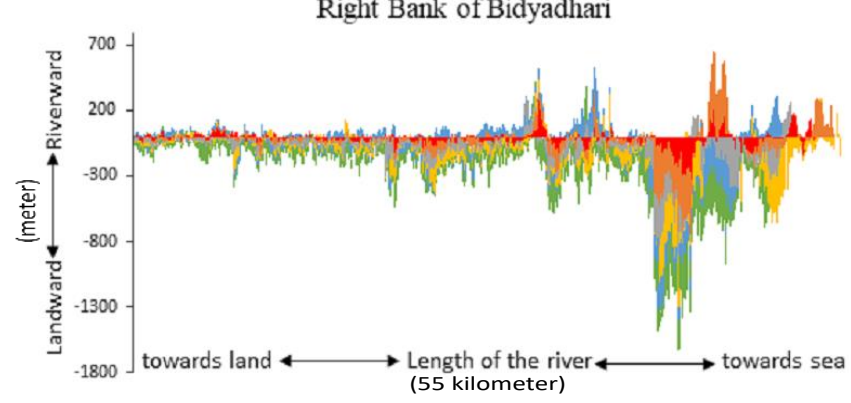

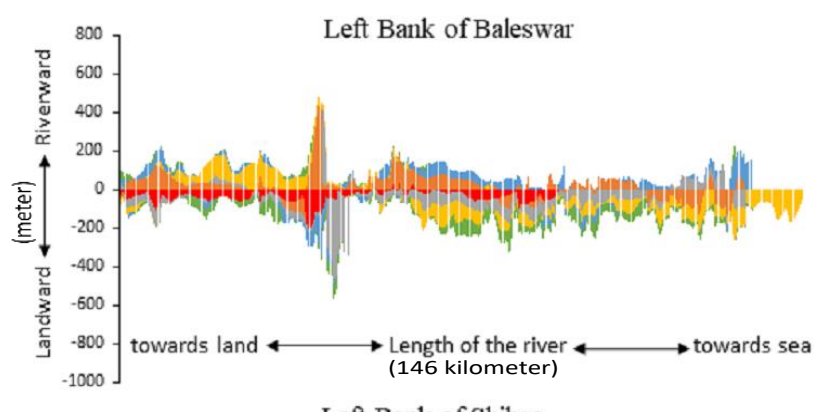

Left Bank of Shibsa

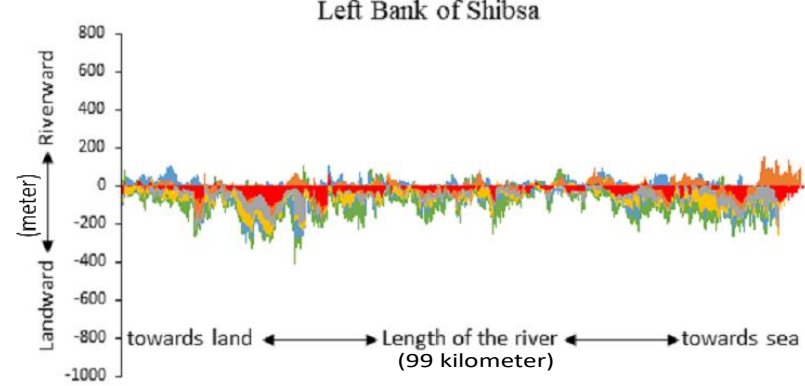

Left Bank of Bidyadhari

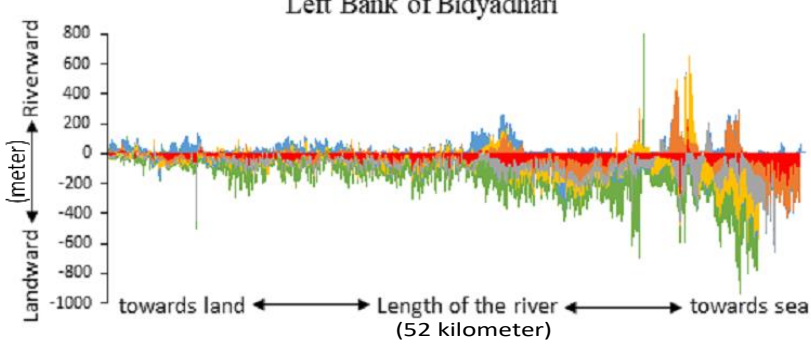

Figure 6: Graphical representation of net bank-line movement of Baleswar, Shibsa and Bidyadhari Rivers

The Bara Pangga River is a small river that absorbs the direct impact of the sea waves unlike other rivers whose coastal part goes through the force rather than the upstream part. As a result, both banks of the river underwent diverse alterations in every interval of the study period. Figure 7 shows that the riverbanks have mostly undergone landward movement. The riverward movement is observed to be much lesser compared to landward.

The left bank of the Harinbhanga River had a maximum landward movement near about $300 \mathrm{~m}$ and a maximum riverward movement, slightly more than $200 \mathrm{~m}$. Though the maximum bank-line change is found near the coast, the left bank of the river underwent random changes for almost every location in each interval of the observation period. Figure 7 represents the random landward and riverward shifting of the riverbank along the channel. The graph shows that the right bank has undergone main changes along the bank-line near the coast i.e., at the downstream of the channel or the river mouth. During the year 19892003, the right bank maintained a balanced movement along the river which is found to be less than $100 \mathrm{~m}$ until reaches the coast. The bank-line showed almost a similar pattern during 2003-2018.

Except for very few locations, the landward and riverward movement is found to be almost identical to the River Raimangal. The left bank endures with a maximum riverward displacement of $310 \mathrm{~m}$ during 2008-2013 which is the highest for the bank-line considering the whole study period (Figure 7). The right bank of the Raimangal River resembled similar characteristics of the left bank. Being closer to the Bay of Bengal, the Raimangal River is found to experience continuous and random bank-line deformation during the study period along both the left bank and right bank.

Overall, the study highlights the highest average landward and riverward movement occurred to be within $120 \mathrm{~m} / \mathrm{year}$ and $85 \mathrm{~m} /$ year respectively along the bank-lines for the rivers of Sundarbans. This indicates that the eroding rates are high among the rivers. Analysis reveals that the highest bank-line movement is less than $100 \mathrm{~m} /$ year observed more often in rivers like Shibsa, Arpangasia and Raimangal whereas Baleswar, Pussur, Bara Pangga and Harinbhanga within $150 \mathrm{~m} /$ year. Bidyadhari shows the highest rate of bank-line movement which is $320 \mathrm{~m} / \mathrm{year}$ along the right bank. Increased rates of erosion at the downstream region could be one of the reasons for such a high rate. Even though other research also focused on monitoring shoreline change especially along the coast of Bangladesh using remotely sensed data (Khan and Hussain, 2018) or based on a combination of DSAS and remote sensing (Sarwar and Woodroffe, 2013), this is the first study using the application of DSAS for bank-line analysis along the main channels within the mangrove forest Sundarbans so far to the author's knowledge. 
According to Brammer (2014), local small erosion has been observed along the south-western coastal region of Bangladesh. The rates are much less than the erosion rate of $200 \mathrm{~m} /$ year as reported by Vidal (2013) in the Sundarbans area which shows the quite similar result with respect to the present study except for the Bidyadhari River. Besides a geo-spatial approach based on the influence of erosion-accretion in Sundarbans concedes that Bulcherry and Dalhousi islands of Bidyadhari River were subjected to erosion since 1975. Uninhabited regions within the mangrove forest are more affected by erosion while most of the accretion occurred within the inhabited regions in the eastern part of the Sundarbans region (Sahana and Sajjad, 2019).

The aim of this study is to check the dynamic nature of river bank-lines using DSAS tool using the delineated bank-lines. This study successfully captured the scenarios of river- and land-ward movement of river bank-lines within a timescale of three decades. The obtained results are difficult to compare with other studies as no similar study was found covering the Sundarbans region.
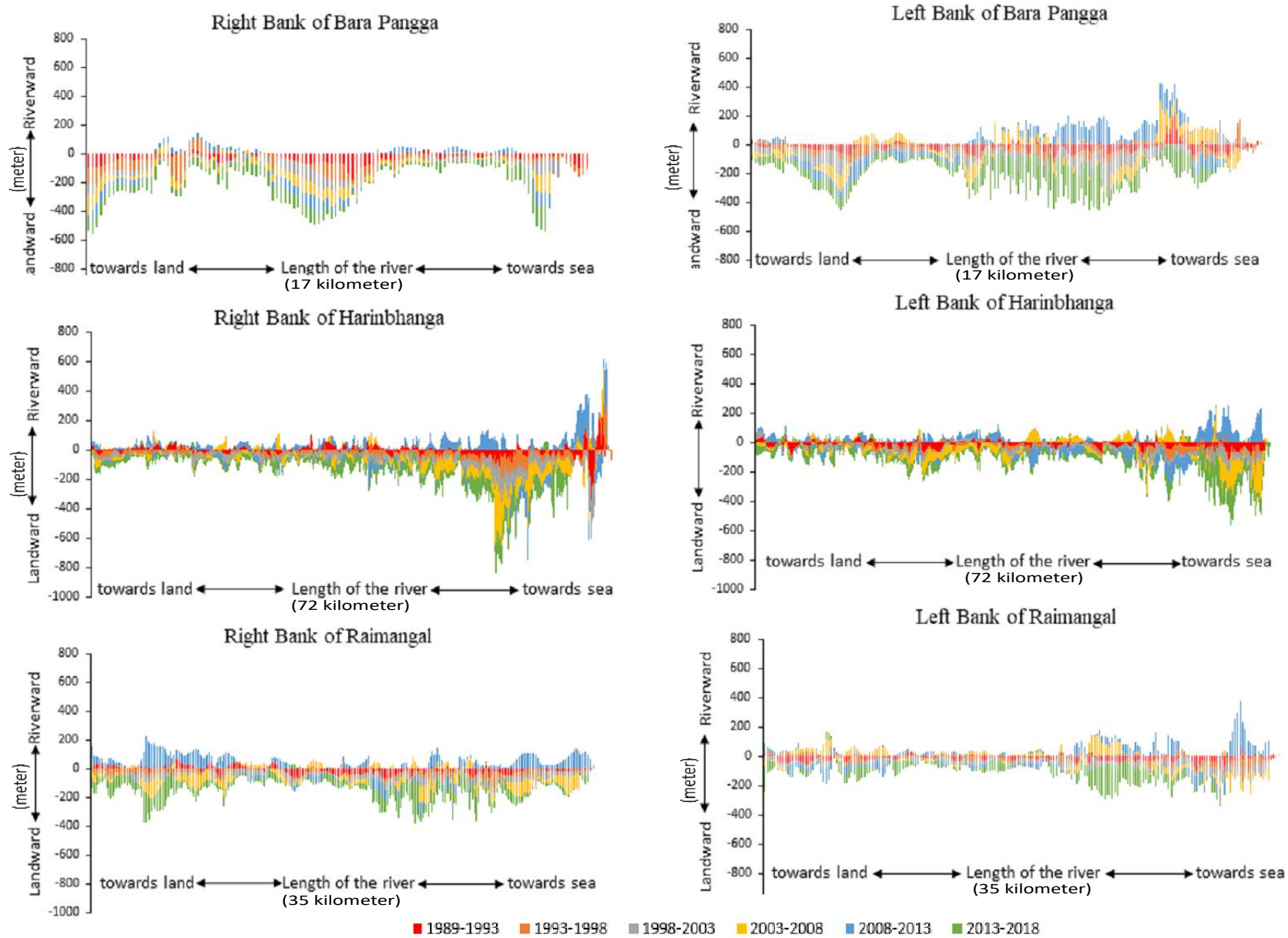

Figure 7: Graphical representation of net bank line movement of Bara Pangga, Harinbhanga and Raimangal Rivers

\section{CONCLUSIONS}

The present study has shown that the DSAS tool of GIS successfully extracted valuable information on the dynamics of river bank-lines in terms of landward and riverward retreats. Even though wide applications of DSAS have been observed for delineating shorelines especially, this is possibly the first study using DSAS for purpose of bank-line analysis. Results interpret that from 2013 to 2018 rates of erosion has dominated more compared to few other analyses. At the downstream of the rivers (proximity to coast) rates of erosion have increased rapidly during this period, especially near the open coast. From 2008 to 2013 rates of accretion dominated at a high amount all over the rivers compared to the next five years. Before the year 2000's rates of erosion-accretion were comparatively much less than after the year 2000. Sundarbans on the Indian side is eroding at a higher rate compared to the Bangladesh side.

This study furthermore can be helpful for future research works, although the findings are limited within highresolution satellite images which would help to obtain results more precisely.

\section{ACKNOWLEDGEMENTS}

The authors would like to express their gratitude to the Department of Civil Engineering, Military Institute of Science and Technology (MIST), Dhaka, Bangladesh. The authors are also thankful to the editors and anonymous reviewers for providing insightful suggestions and comments to improve the manuscript. 


\section{REFERENCES}

Appeaning Addo, K., Walkden, M., and Mills, J. P. (2008). 'Detection, measurement and prediction of shoreline recession in Accra, Ghana', International Society for Photogrammetry and Remote Sensing, 63(5), 543-558.

Benumof, B. T., Storlazzi, C. D., Seymour, R. J. and Griggs, G. B. (2000). 'The relationship between incident wave energy and sea cliff erosion rates: SanDiego County, California', Journal of Coastal Research, 17, 1162-1178.

Brammer, H. (2014). 'Bangladesh's dynamic coastal regions and sea-level rise', Climate Risk Management, 1, 51-62.

Cohen, M.C.L. and Lara R.J. (2003). 'Temporal changes of mangrove vegetation boundaries in Amazonia: application of GIS and remote sensing techniques', Wetland Ecology Management, 11(4), 23-231.

Collins, B. D. and Sitar, N. (2008). 'Processes of coastal bluff erosion in weakly lithified sands, Pacifica, California, USA', Geomorphology, 97, 483-501, doi: 10.1016/j.geomorph.2007.09.004.

Ellison, J. C. and Zouh, I. (2012). 'Vulnerability to climate change of mangroves: Assessment from Cameroon, Central Africa', Biology, 1, 617-638.

Esteves, L. S., William, J. J. and Brown, J. M. (2011). 'Looking for evidence of climate change impacts in the eastern Irish Sea', Natural Hazards and Earth System Sciences, 11, 1641-1656, doi: 10.5194/nhess-11-1641-2011.

Frazier, P. S. and Page, K. J. (2000). 'Water body detection and delineation with Landsat TM data', Photogrammetric Engineering and Remote Sensing, 66(12), 1461-1467.

Gilman, E., Ellison, J. C., and Coleman, R. (2007). 'Assessment of mangrove response to projected relative sea-level rise and recent historical reconstruction of shoreline position', Environmental monitoring and assessment, 124(1-3), 105130.

Hapke, C.J., Reid, D. and Richmond, B. (2009). 'Rates and trends of coastal change in California and the regional behaviour of the beach and cliff system', Journal of Coastal Research, 25(3), 603-615.

Hegde, A.V. and Akshaya B.J. (2015). 'Shoreline transformation study of Karnataka Coast: Geospatial Approach', Aquatic Procedia, 4, 151-156.

Ji, L., Geng, X., Sun, K., Zhao, Y. and Gong, P. (2015). 'Target detection method for water mapping using Landsat 8 OLI/TIRS imagery', Water, 7(2), 794-817.

Kanwal, S., Ding, X., Sajjad, M., and Abbas, S. (2019). 'Three decades of coastal changes in Sindh, Pakistan (1989-2018): a geospatial assessment', Remote Sensing, 12(1), 8, https://doi.org/10.3390/rs12010008.

Katz, O. and Mushkin, A. (2013). 'Characteristics of sea-cliff erosion induced by a strong winter storm in the eastern Mediterranean', Quaternary Research, 80, 20-32, doi: 10.1016/j.yqres.2013.04.004.

Khan, E. and Hussain, N. (2018). 'Coastline dynamics and raising landform: a geo-informaticsbased study on the Bay of Bengal, Bangladesh', The Indonesian Journal of Geography, 50(1), 41-48.

Kuehl, S. A., Allison, M. A., Goodbred, S. L., and Kudrass, H. (2005). 'The Ganges-Brahmaputra Delta'. In book: River Deltas - Concepts, Models, and Examples, Edited by Giosan L. and Bhattacharya J., 413-434.

Kuleli, T. (2010). 'Quantitative analysis of shoreline changes at the Mediterranean Coast in Turkey', Environmental Monitoring and Assessment, 167(1-4), 387-397.

Masocha, M., Dube, T., Makore, M., Shekede, M.D. and Funani, J. (2018). 'Surface water bodies mapping in Zimbabwe using landsat 8 OLI multispectral imagery: A comparison of multiple water indices', Physics and Chemistry of the Earth, Parts A/B/C 106, 63-67.
Matin, N. and Hasan, G.M.J. (2021). 'A quantitative analysis of shoreline changes along the coast of Bangladesh using remote sensing and GIS techniques', Catena, 201. https://doi.org/10.1016/j.catena.2021.105185.

McIvor, A. L., Spencer, T., Möller, I., and Spalding, M. (2013). 'The response of mangrove soil surface elevation to sea level rise', Natural Coastal Protection Series: Report 3, Cambridge Coastal Research Unit Working Paper 42, ISSN 2050-7941.

Mikhailov, V. N. and Dotsenko, M. A. (2007). 'Processes of delta formation in the mouth area of the Ganges and Brahmaputra rivers', Water Resources, 34(4), pp. 385-400.

Moore, L. J. and Griggs, G. B. (2002). 'Long-term cliff retreat and erosion hotspots along the central shores of the Monterey Bay National Marine Sanctuary', Marine Geology, 181(1-3), 265283, doi: 10.1016/S0025-3227(01)00271-7.

Moussaid, J., Fora A.A., Zourarah B., Maanan M. and Maanan M. (2015). 'Using automatic computation toanalyze the rate of shoreline change on the Kenitra coast, Morocco', Ocean Engineering, 102(1), 71-77.

Murty, T. S., and Henry, R. F. (1983). 'Tides in the Bay of Bengal', Journal of Geophysical Research: Oceans, 88(C10), 60696076, doi: 10.1029/JC088iC10p06069.

Nabi, M.R., Rashid, M. S. and Hossain, M.I. (2016). 'Historical Bank-line Shifting Since 1760s: A GIS and Remote Sensing Based Case Study of Meghna River Plate of Rennell's Atlas', International Journal of Scientific and Research Publications, 6(12), 473-483.

Natesan, U., Thulasiraman, N., Deepthi, K. and Kathiravan, K. (2013). 'Shoreline change analysis of Vedaranyam coast, Tamil Nadu, India', Environmental Monitoring and Assessment, 185(6), 5099-5109.

Nguyen H. H., McAlpine C., Pullar D., Leisz S.J. and Galina G., (2015). 'Drivers of coastal shoreline change: case study of Hon Dat coast, Kien Giang, Vietnam', Environmental Management, 55(5), 1093-1108.

Rahman, A.F., Dragoni, D. and El-Masri, B., (2011). 'Response of the Sundarbans coastline to sea level rise and decreased sediment flow: a remote sensing assessment', Remote Sensing of Environment, 115(12), 3121-3128.

Sahana, M. and Sajjad, H., (2019). 'Assessing influence of erosion and accretion on landscape diversity in Sundarban Biosphere Reserve, Lower Ganga Basin: a geospatial approach'. Quaternary Geomorphology in India, Springer, 191-203, https://doi.org/10.1007/978-3-319-90427-6_10.

Sarwar, M.G.M. and Woodroffe, C.D. (2013). 'Rates of shoreline change along the coast of Bangladesh', Journal of coastal conservation, 17(3), 515-526.

Sathirathai, S. and Barbier E.B., (2001). "Valuing mangrove conservation in southern Thailand', Contemporary Economic Policy, 19(2), 109-122.

Sheik, M. and Chandrasekar (2011). 'A shoreline change analysis along the coast between Kanyakumari and Tuticorin, India, using digital shoreline analysis system'. Geo-spatial Information Science, 14(4), 282-293.

Sarkar, A., Garg, R.D., and Sharma, N., (2012). 'RS-GIS based assessment of river dynamics of Brahmaputra river in India', Journal of Water Resource and Protection, 4, 63-72.

Souza Filho, P. W. M., Martins, E. do S. F., and Costa, F. R. (2006). 'Using mangroves as a geological indicator of coastal changes in the Bragança macrotidal flat, Brazilian Amazon: a remote sensing data approach', Ocean and Coastal Management, 49(7-8), 462-475.

Thieler, E. R., Himmelstoss, E. A., Zichichi, J. L., and Ergul, A. (2009). 'Digital Shoreline Analysis System (DSAS) version 4.0-An ArcGIS extension for calculating shoreline change', US Geological Survey Report, 2008-1278. 
To, D.V. and Thao, P.T.P., (2008). 'A shoreline analysis using DSAS in Nam Dinh Coastal Area', International Journal of Geoinformatics, 4(1), 37-42.

Vidal, J. (2013). 'Tigers under threat from disappearing mangrove forest', The Guardian, accessed on 10 Dec 2020.
Wenbo, L., Du, Z., Ling, F., Zhou, D., Wang, H., Gui, Y., Sun, B. and Zhang, X. (2013). 'A comparison of land surface water mapping using the normalized difference water index from TM, ETM+ and ALI', Remote Sensing, 5(11), 5530-5549. 